\title{
Peptic Hydrolysis of Ovalbumin Modified by Acetylation ${ }^{1,2}$
}

\author{
Otto W. Neuhaus ${ }^{3}$ and Lila Miller \\ From the Department of Biological Chemistry, Medical School, \\ University of Michigan, Ann Arbor, Michigan
}

Received December 26, 1956

\section{INTRODUCTION}

With the availability of newer techniques, a greater variety of synthetic substrates, and more reliable analytical data for protcins, the views regarding the specificity of crystalline pepsin have changed. A theory of broader specificity has displaced the limited one which was based on the hydrolysis of acylated synthetic peptides, particularly those involving glutamic acid in combination with tyrosine or phenylalanine $(1,2)$. Three occurrences support this change: $(a)$ the hydrolysis of peptides that do not contain this combination of amino acids (3-6), (b) the liberation of amino nitrogen in excess of the equivalents of those amino acids in the protein molecule $(7)$, and $(c)$ the exposure of nonaromatic N-terminal groups during hydrolysis (8-11).

The modification of particular functional groups in the protein-substrate is also a possible means of identifying the structure required for hydrolysis by pepsin. Previous studies with formylated and with acetylated ovalbumin indicated the requirement of primary amino groups in the substrate (12-14). This type of study bears reinvestigation as the modified proteins were insoluble and the presence of substituents on other groups was not determined.

In this report the peptic digestion of the soluble acetylated ovalbumins

${ }^{2}$ From the dissertation of Otto W. Neuhaus submitted to the Horace H. Rackham School of Graduate Studies, University of Michigan, in partial fulfillment of the requirement for the Ph.D. degree.

2 A preliminary report of this work was presented at the meeting of the American Society of Biological Chemists, New York, April 1952.

${ }^{3}$ Present address: Dept. of Anatomy, Wayne State University, Detroit, Mich. 
is compared with that of the native protein. The acetylated products are less susceptible but not completely inert to pepsin.

\section{Materials and Methods}

Ovalbumin prepared according to the procedure of Kekwick and Cannan (15) was crystallized 4 or 5 times, freed of sulfates by dialysis, and then lyophilized. Samples of these preparations were acetylated with ketene $(16,17)$.

The acetyl derivative in which only amino groups were blocked, $N$-acetylovalbumin, ${ }^{4}$ was prepared by exposing $15 \mathrm{ml}$. of a $3 \%$ solution of the protein in $3 \mathrm{M}$ acetate buffer (pH 5.5) to ketene for $30 \mathrm{~min}$. For the more extensively acetylated product, $N, O$-acetylovalbumin, ${ }^{4} 25$-ml. samples of a $2 \%$ solution of protein in $0.75 M$ borale buffer ( $\mathrm{pH} \mathrm{9.0)}$ ) were trealed with ketene for 40 min. At the end of the reaction period, immediate adjustment to $\mathrm{pH} 8.0$ prevented the hydrolysis of ester linkages. All acetylations were conducted at $15-20^{\circ} \mathrm{C}$, and the specified $\mathrm{pH}$ 's were maintained by successive additions of $\mathrm{NaOH}$.

The two acetylated products were isolated in essentially the same manner: dialysis against flowing distilled water to remove the acetate ions, filtration through glass wool, adjustment to $\mathrm{pH} 4.7$, and then saturation with $\mathrm{Na}_{2} \mathrm{SO}_{4}$ to precipitate the modified proteins. Aqueous solutions of these precipitates, freed of sulfate by dialysis, were lyophilized.

For the determination of the total number of acetyl groups and those labile at $\mathrm{pH} 10$, the preliminary alkaline hydrolyses were based on the procedures of Herriott (19) and of Sandor and Tabone (20). The conditions for the distillation were a modification of those used by Miller and Stanley (21) and by Herriott (19).

To liberate all the acetyl groups, a strongly basic medium and heating for $8 \mathrm{hr}$. at $100^{\circ} \mathrm{C}$. are required, e.g., $1-2-\mathrm{ml}$. aliquots plus $1 \mathrm{ml} .4 \mathrm{~N} \mathrm{NaOH}$ diluted to $4 \mathrm{ml}$. Milder conditions hydrolyzed the labile acetyl groups, viz., a mixture of 2-ml. aliquots, plus $1 \mathrm{ml}$. borate buffer $(\mathrm{pH} \mathrm{10})$ and $2 \mathrm{ml}$. water incubated at $35.5^{\circ} \mathrm{C}$. for $24 \mathrm{hr}$. All hydrolyzates were diluted to $10 \mathrm{ml}$. In the analysis of these hydrolyzates for acetate, 1-3-ml. aliquots were diluted to $4 \mathrm{ml}$. and mixed with $2 \mathrm{ml}$. of $2 \mathrm{~N}$ citric acid. After the initial distillation under reduced pressure $\left(70^{\circ} \mathrm{C} ., 20-25 \mathrm{~mm}\right.$.) at the rate of $1 \mathrm{ml} . / \mathrm{min}$., the last traces of acetic acid were removed by two successive distillations of $4 \mathrm{ml} . \mathrm{CO}_{2}$-free water each time. The distillate was titrated with $0.02 \mathrm{~N} \mathrm{NaOH} .^{5}$

Under these established conditions the average recovery of $0.01-0.04$ millimole of acetic acid was $99.6 \%$ and, in the presence of alanine, pepsin, or ovalbumin, 95.7, 94.1, and 102\%, respectively. The acetyl recoveries from acetylalanine and of $N, O$-diacetyltyrosine under the same conditions were 97.4 and $99.9 \%$, respectively. In all determinations, except for aqueous acetic acid, a blank correction was made for the minor amount of volatile acids arising from an equivalent amount of the unacetylated compound.

${ }^{4}$ For convenience, $N$-acetyl- and $N, O$-acetylovalbumin refer to the products obtained by acetylation at $\mathrm{pH}$ 's 5.5 and $9.0-9.5$, respectively.

${ }^{5}$ The $\mathrm{CO}_{2}$ was removed by boiling the distillate for 5 sec., and the solution was protected from the $\mathrm{CO}_{2}$ of the air while cooling. 
The esterified hydroxyphenyl groups were determined by the so-called "pH 8pH 11 method" of Herriott as modified by Miller (22) and by Rovery and Desnuelle (16). In this method, based on the reduction of the Folin-Ciocalteau reagent by tyrosine but not by $O$-acetyltyrosine, the optical densities were measured on the Klett-Summerson photoelestric colorimeter $(600 \mathrm{~m} \mu$ filter). For all analyses of the proteins, the aliquots used gave optical densities equivalent to that of $20-40$ $\mu \mathrm{g}$. of tyrosine.

The total nitrogen was determined by micro-Kjeldah ${ }^{6}(23)$, and the amino nitrogen by the Van Slyke procedure (24). In the latter, a 20-min. reaction period at $23-25^{\circ} \mathrm{C}$. was employed for the determination of the total free-amino nitrogen of the proteins, and a 3-min. period for measurement of the increases in $\alpha$-amino nitrogen resulting from digestion. To prevent artifacts from light-catalyzed reactions of tyrosine, the reaction chamber was covered with black paper (25).

The crystalline pepsin prepared from the 1:10,000 Parke-Davis product by the procedure of Northrop (26) had a specific activity of $0.17[\mathrm{Hb}]$ units/mg. protein $\mathrm{N}$.

In most cases the substrates were dissolved in water or $\mathrm{NaCl}(1 \%)$, and the small amount of insoluble material was removed by centrifugation. Solution of the $N, O$-acetylalbumin, however, required the addition of $0.1 \mathrm{~N} \mathrm{NaOH}$ to bring the $\mathrm{pH}$ to 6.0 . After complete solution, $0.1 \mathrm{~N} \mathrm{HCl}$ was rapidly added. The $\mathrm{pH}$ of all substrates was adjusted to 1.5 before the addition of the pepsin solution (pH 1.7). The average concentration of the substrate $N$ was $4.15 \mathrm{mg} . / \mathrm{ml}$, and the amount of pepsin added supplied an activity of $3.9-4.2 \times 10^{-3}[\mathrm{Hb}]$ units $/ \mathrm{mg}$. of substrate $N$. All digestions were conducted at $30 \pm 1^{\circ}$, and both substrate and enzyme controls were run with each.

The degree of hydrolysis was measured by (a) the increases in $\alpha$-amino $\mathrm{N}$ and (b) the decrease in the nitrogen content of the fraction precipitated by trichloroacetic acid (TCA), $10 \%$ concentration (27).

\section{Results and Discussion}

Analytical data for the substrates are presented in Table I. The values for the total nitrogen and the amino groups per molecule of ovalbumin agree with those reported in the literature $(7,28)$. The observed tyrosineplus-tryptophan content as measured by the Folin-Ciocalteau reaction is equivalent to 12 residues per molecule, a good agreement with the reported 9 tyrosine and 2.6 tryptophan residues as determined by other methods (28).

The position of the acetyl groups in the $N$-acetylovalbumin is practically limited to the amino groups as indicated by the agreement of the decrease in the number of primary amino groups with the number of acetyl groups stable at $\mathrm{pH} 10$. The 14 or 15 groups acetylated represent

6 The color standard used routinely in titrating the distillates consists of $10 \mathrm{ml}$. of the boric acid indicator solution plus $40 \mathrm{ml}$. of $2 \%$ boric acid previously adjusted to $\mathrm{pH} 4.75$, the point of inflection in the titration of ammonium borate with hydrochloric acid. 
TABLE I

Effect of Acetylation on Certain Reactive Groups in Crystalline Ovalbumin

All data are expressed on moisture-, ash-free basis.

\begin{tabular}{|c|c|c|c|c|c|c|c|}
\hline \multirow{2}{*}{$\begin{array}{l}\text { Ovalbumin and its } \\
\text { acetyl derivatives }\end{array}$} & \multirow{2}{*}{ Total nitrogen } & \multicolumn{2}{|c|}{ Amino groups } & \multirow{2}{*}{$\begin{array}{c}\text { Tyrosine ratio, } \\
\mathrm{pH} 8 / \mathrm{pH} 11 \\
\text { value }\end{array}$} & \multicolumn{3}{|c|}{ Acetyl groups ${ }^{a}$} \\
\hline & & Free & $\left|\begin{array}{c}\text { Sub- } \\
\text { stituted }\end{array}\right|$ & & Total & pH 100 & $\begin{array}{l}\mathrm{pH} 10 \\
\text { stable }\end{array}$ \\
\hline & per cent & $\begin{array}{l}\text { grou } \\
\text { mol }\end{array}$ & $\begin{array}{l}\text { ps per } \\
\text { eculec }\end{array}$ & ratio & groul & s per mo & lecule \\
\hline \multicolumn{8}{|l|}{ Crystalline } \\
\hline $\mathrm{A}^{b}$ & 15.72 & 20 & 0 & 0.97 & & & \\
\hline $\mathrm{B}^{b}$ & 15.79 & 22 & 0 & 1.02 & & & \\
\hline \multicolumn{8}{|l|}{$N$-Acetyl } \\
\hline A & 15.79 & 6 & 14 & 1.00 & 17 & 2 & 15 \\
\hline B & 15.79 & 7 & 15 & 0.97 & 15 & 2 & 13 \\
\hline \multicolumn{8}{|l|}{$N, O$-Acetyl } \\
\hline $\mathrm{B}, \operatorname{lot} \mathrm{I}$ & 15.28 & 1 & 21 & 0.47 & 57 & 20 & 37 \\
\hline $\mathrm{B}, \operatorname{lot} \mathrm{II}$ & 14.79 & 1 & 21 & 0.44 & 59 & 20 & 39 \\
\hline
\end{tabular}

${ }^{a}$ Corrected by an ovalbumin blank.

${ }^{b} \mathrm{~A}$ and $\mathrm{B}$ were crystallized 4 and 5 times, respectively.

$c$ In the calculation of groups per molecule, 46,000 was used for the molecular weight of ovalbumin and the $N$-acetyl derivative, and 48,000 for the $N, O$-derivative, based on the nitrogen and acetyl content.

$70 \%$ of the tolal free-amino groups in the unmodified protein. It is possible that the incomplete acetylation of these at $\mathrm{pH} 5.6$ is due to the limited reaction period $(30 \mathrm{~min}$.) necessitated by the tendency of the protein to precipitate. However, acetylation by acetic anhydride under conditions that blocked $90-95 \%$ of the free-amino groups in serum albumin (29) resulted in substitution on only $72 \%$ of those in ovalbumin. These observations suggest that under experimental conditions used in this study, $28-30 \%$ of the amino groups in the ovalbumin are unreactive to both acetylating agents.

In the $N, O$-acetylalbumin, the acetyl content averaged 58 groups per molecule, which is more than three times that of the $N$-acetyl derivative. The substituted amino groups account for 21 of the 38 acetyls stable at $\mathrm{pH} 10$, and the esterified tyrosine residues account for $4-5$ of the 20 labile acetyls. Thus, 32 acetyl groups or more than half of them are in unidentified position. It is possible that these are esters of aliphatic hydroxyls but not thioesters. Although the sulfhydryls of denatured egg albumin acetylate readily, those in the native protein are inert to ketene. 


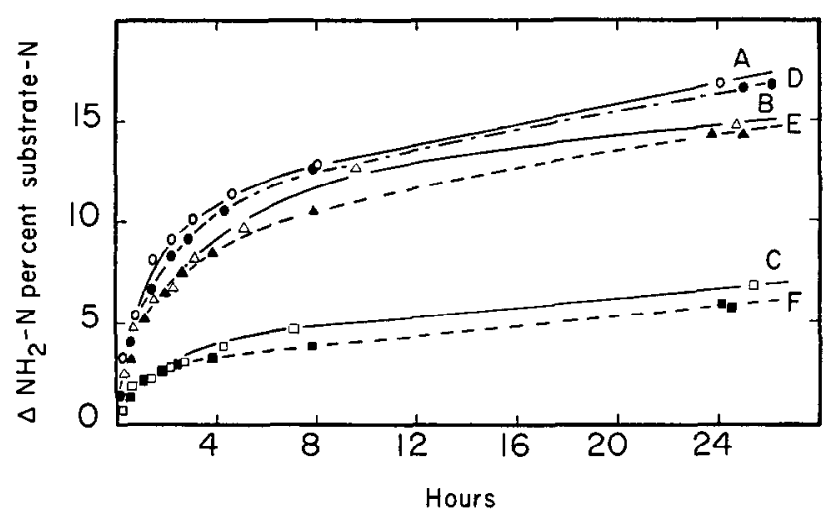

FIg. 1. Increases in amino $\mathrm{N}$ occurring during peptic digestion of ovalbumin and its acetyl derivatives. Curves $A$ and $D$ represent the native protein; $B$ and $E$, the $N$-acetyl derivative; $C$ and $F$, the $N, O$-acetyl derivative. In the digest the $\mathrm{pH}$ was 1.6, and the concentration of crystalline pepsin supplied an activity of $3.9-4.2 \times 10^{-3}[\mathrm{Hb}]$ units/mg. substrate $\mathrm{N}$ which ranged between 3.04 and 4.51 $\mathrm{mg}$./ml. In experiments $D, E$, and $F, \mathrm{NaCl}(0.45 \%)$ was present. In all experiments the temperature was $30^{\circ}$. The data are corrected for the enzyme controls i.e., autolysis.

Furthermore these thioesters hydrolyze rapidly in the presence of alkali at room temperature $(17,18)$.

The course of the peptic hydrolyses of these proteins is shown in Figs. 1 and 2 as measured by the increase in amino $\mathrm{N}$ and by the fraction precipitable by trichloroacetic acid, respectively. In the experiments represented by curves $A, B$, and $C$, water and hydrochloric acid served as the solvent and, in the others, $D, E$, and $F$, sodium chloride was also present to prevent the gelation of the $N$-acetyl protein. The presence of salt $(0.45 \%$ in the digest) does not significantly alter the course of the hydrolysis.

When $70 \%$ of the primary amino groups have been acetylated (as exemplified by the $N$-acetylalbumin, curves $B$ and $E$ in both Figs. 1 and 2), the susceptibility of the molecule to peptic digestion was decreased. The liberation of amino groups was approximately $80-90 \%$ of that observed for the native protein throughout the experimental period (curves $A$ and $D$ compared with $B$ and $E$ in Fig. 1). The fractions of substrate $\mathrm{N}$ precipitated by TCA from $N$-acetylalbumin undergoing digestion were larger than those obtained from the digests of the native albumin at comparable time intervals (Fig. 2, curves $A, B, D$, and $E$ ). 


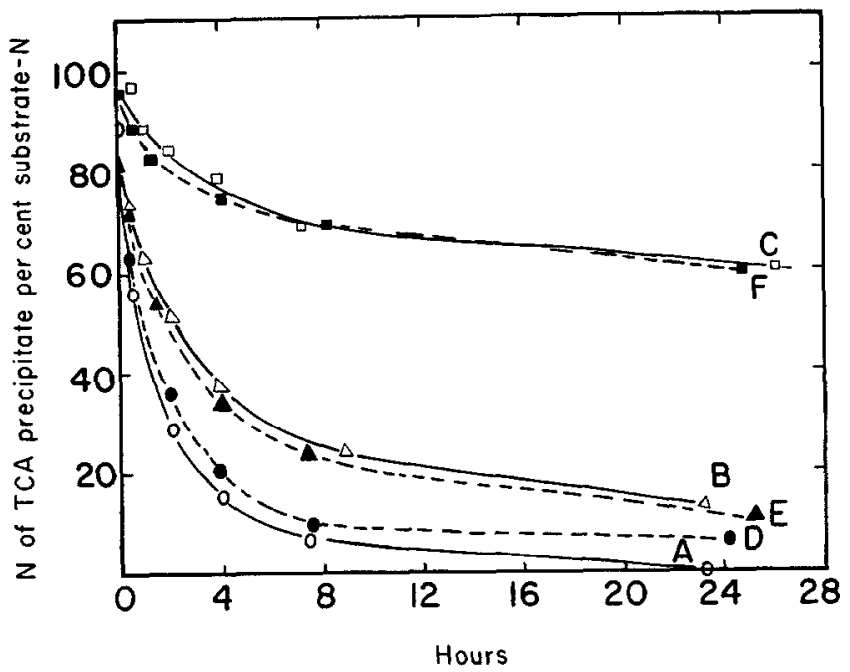

FIG. 2. The nitrogen content of the TCA-precipitated fractions from the peptic digest of ovalbumin and its acetyl derivatives. The designation of the curves and the experimental conditions accompany Fig. 1.

This small decrease in the digestibility produced by acetylation of 15 amino groups stands in marked contrast to the observation of Tazawa who reported the complete resistance of an $N$-acetylovalbumin to pep$\sin (14)$. In his product, all the amino groups were acetylated as measured by the amino N. It may well be that other groups were also blocked as the product was obtained by prolonged acetylation with acetic anhydride, followed by alkaline hydrolysis to restore the esterified hydroxyl groups. Furthermore, the total number of acetyl groups was not determined. If the acetylation in Tazawa's derivative was limited to the amino groups, then it would appear that the seven unmodified groups in our $N$-acetyl product may significantly determine the susceptibility of this protein to the action of pepsin.

The hydrolysis of the $N, O$-acetyl protein is strikingly limited as measured by both indices (curves $C$ and $F$ in Figs. 1 and 2). At the end of a 24-hr. digestion period, only one-third as many bonds had been cleaved as in the native protein, and $60 \%$ of the substrate $\mathrm{N}$ remained in the fraction precipitable by TCA.

Restoring of the free phenolic groups in the $N, O$-acetyl protein by alkaline ( $\mathrm{pH} \mathrm{12)} \mathrm{hydrolysis} \mathrm{at} \mathrm{room} \mathrm{temperature} \mathrm{for} 30 \mathrm{~min}$. increased only slightly the degree of digestion. The number of peptide bonds 
cleaved enzymically during an 8-hr. digestion of this material was greater by three bonds per molecule than that observed for the original $N, O$ acetylovalbumin. The degree of hydrolysis, however, remained less than half that observed with either the native or the $N$-acetyl protein. Therefore the marked resistance of the $N, O$-compound is not associated exclusively with the esterified tyrosine residues but is also related to the additional 6 or 7 amino groups blocked in this compound but free in the $N$-acetyl derivative and to the acetylation of the unidentified groups. The fact that pepsin digested each of the acetylated ovalbumins used in this study opens to question the degree of acetylation or formylation in those modified ovalbumins completely inert to pepsin $(14,13)$.

The peptide bonds split by pepsin cannot be limited to those involving the tyrosine and phenylalanine residues as even in the most extensively acetylated derivative, $N, O$-acetylovalbumin, 33 bonds were hydrolyzed, which is greater than the total number of these residues. This observation and the cleavage of 85 and 75 bonds in the native and in the $N_{\text {-acetyl }}$ protein support the broad specificity of pepsin toward protein substrales.

\section{SUMMARY}

1. Two types of acetylated ovalbumin derivatives designated as $N$ and $N, O$-acetylovalbumin were prepared by treatment with ketene at pH's 5.6 and 9.0 , respectively.

2. Both limited and extensive acetylation decreases the digestibility of ovalbumin by crystalline pepsin.

3 . The limited digestion of the $N, O$-acetylovalbumin may be attributed to three influences: the acetyl groups on the seven amino groups unsubstituted in the $N$-acetyl derivative, those on the tyrosyl residues, and those in unidentified positions, rather than to any one of these.

4. The results are in agreement with the view that pepsin is of broad specificity toward protein substrates.

\section{REFERENCES}

1. Fruton, J. S., And Bergmann, M., J. Biol. Chem. 127, 627 (1937).

2. Bergmann, M., Advances in Enzymol. 2, 49 (1942).

3. Harrington, C. R., ANd Pitt-Rivers, R. V., Nature 154, 301 (1944).

4. Dekker, C. A., TAylor, S. P., and Fruton, J. S., I. Biol. Chem. 180, 155 (1949).

5. BaKer, L. E., J. Biol. Chem. 193, 809 (1951).

6. Baker, L. E., J. Biol. Chem. 211, 701 (1954).

7. Caluvert, H. O., J. Biol. Chem. 102, 73 (1933). 
8. Desnuelle, P., Rovery, M., And Bonjour, G., Biochim. et Biophys. Acta 5, $116(1950)$.

9. Sanger, F., ANd Tuppy, H., Biochem. J. 49, 481 (1951).

10. Sanger, F., AND Thompson, E. O. P., Biochem. J. 63, 366 (1953).

11. Courts, A., Biochem. J. 69, 382 (1955).

12. Johannesohn, F., Biochem. Z. 83, 28 (1917).

13. Hugounenq, L., ANd Loiseleur, J., Bull. soc. chim. biol. 7, 955 (1925).

14. TAzaWA, Y., Acta Phytochim. (Japan) 13, 117 (1943).

15. Kerwick, L. A., and Cannan, R. K., Biochem. J. 30, 227 (1936).

16. Rovery, M., and Desnuelue, P., Biochim. et Biophys. Acta 2, 514 (1948).

17. Desnuelle, P., And Rovery, M., Biochim. et Biophys. Acta 1, 497 (1947).

18. Fraenkel-Conrat, H., J. Biol. Chem. 152, 385 (1944).

19. Herriott, K. M., J. Gen. Physiol. 19, 283 (1935).

20. Sandor, G., ANd Tabone, J., Bull. soc. chim. biol. 21, 1254 (1939).

21. Miluer, G. L., and Standey, W. M., J. Biol. Chem. 141, 905 (1941).

22. Miller, G. L., J. Biol. Chem. 146, 339 (1942).

23. Miller, L., and Houghton, J. A., J. Biol. Chem. 159, 373 (1945).

24. Van Slyke, D. D., J. Biol. Chem. 16, 121 (1913).

25. Fraenkel-Conrat, H., J. Biol. Chem. 148, 453 (1943).

26. Northrop, J. H., J. Gen. Physiol. 13, 739 (1930).

27. Miller, L., Searles, O. M., and Sempere, J. H., Arch. Biochem. 19, 359 (1948).

28. Tristram, G. R., Advances in Protein Chem. 5, 83 (1949).

29. Teresi, J. D., J. Am. Chem. Soc. 72, 3972 (1950). 